\title{
高分子溶液 の特性
}

中 島 章 夫**

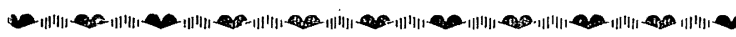

高分子の 分子レベルでの 特性を 把握するための最も端的な方法は, 高分子 を大量の溶媒に溶かし，溶液の物性量を湘定することである。高分子溶液研究 の歴史は古く，その高分子科学における役割はきわめて大きい，湘定技術の樹 立と精密化, 統計および流体力学的手法によるモデル高分子に対する理論の提 案, この両者の拈抗過程の交錯のらえに現在の溶液論が存在している。ある領 域では理諭が，また別の領域では逆に実験が先行しているであろう。自然は “時たま”われわれの前にその真の姿を見せてくれる。“それ”が “真実”であ るか“幻”であるかを見分けるためには，われわれは自然に対して圓欲である と同時に謙譲でなくてはならない。
\end{abstract}

\section{1. 緒論}

“高分子とは何か”といらこと，いいかえると高分子 の特性を高分子溶液論の立場から記述することが筆者に 与えられた課題である。通常, 高分子の“溶液物性”之 呼ばれている研究領域を研究目的に従って大別すると, 一つは溶液物性自体を対象とするものであり，他の一つ は溶液の物性量を通して高分子の分子量や分子量分布。 高分子鎖の形態などを判定したり，また物性量と分子の 立体規則性, 共重合体の組成や組成分布との関連性を調 ベるなど，高分子の分子構造の解明といらことに主眼を おくものの二つに分けることができよう。ここでは後者 の領域すなわち高分子溶液の分子論的な問題を主として とりあげることにする。

高分子の分子としての構造・性質の把握は, 分子を希 薄溶液としてばらばらに分散させ，その物性量を测定す ることによって達成される。現在, 高分子が共有結合に よって構成された真に分子量の大きい分子であることを 疑らものはいないが，この認識は H. Staudinger の肴 薄溶液物性を用いてなされた分子量の測定がその基盤の 一つになっている。

高分子は 1 種類, あるいは 2 種類以上の単量体が共有

* Akio NAKAJIMA 京都大学 (工学部高分子化学教 室·606 京都市左京区吉田本町) 教授・工博

Properties of Polymer Solutions
結合によって数多く連結して形成された分子量の大さい 分子であると定義されるが，単量体の結合様式によって 線状分子，枝分かれ分子，粒状分子，棒状分子など個々 の分子として分散しらる状態から, 二次元や三次元の不 溶性網状構造に至るまで，さまざまな形状が区別され る。単量体の連結ということに注目すると 2 量体以上は いずれも重合体であり，かつ重合度は 1 から心まで連続 的に考えることができるから，高分子(高重合体)と低分 子の間に重合度のうえで明確な境界をつけることはでき ない。単量体に対する法則が 2 量体以上の重合体にもあ てはまるならば, 高重合体の特性といらものは, 単に重 合度が大きくなったために当然出現する性質といらべき である。問題は重合度が大きいために出現する性質，こ れを高分子の特性といらならば，それがどの程度の重合 度から現われるかといらことであるが，これは分子の構 造, 形態と密接に関連してくる。たとえば, 屈曲性の大き い分子と非屈曲性の分子とでは，高分子特性の現われる 重合度の限界は著しく異なってくる。

分子量が大きいといらことのほかに高分子物質が低分 子物質と異なる点は, 高分子の生成が統計的な機構で行 なわれる場合，高分子物質は重合度分布や，組成分布な らびに立体不規則性を示すことである。たとえば単量体 単位が不整炭素を含むよらな場合，生成した個々の高分 子鎖の立体規則性は同一でないであろらし，また共重合 体についても個々の分子鎖の単量体配置様式は異なるで 


\section{現代の高分子。}

あろう。しかしながら、このことはタンパク質に和ける ように生成反応が規制機構で行なわれる場合は論外であ る。タンパク質では物質が指定されるとアミノ酸の結合 順序，結合数が一定で，したがって分子量も一義的に与 亲ら，どの分子をとりあげても全く同一であることに なる。

Natta（1955）による立体特異性重合の確立は合成面 で分子鎖の立体配置 (configuration) の制御を可能にし たといら点で特筆すべきである。Nattaの発明により高 分子の構造論は大きい飛躍を遂げ，高分子の結晶で得 られた知見は, 単離された単独鎖のコンホメーション (conformation) を，模型鎖としてでなく実際鎖として 種々の高分子化合物についてその分子パラメーターによ って表示することを可能にした。屈曲性高分子につい てこのようにして求められた特性比 (characteristic ratio)は分子定数とも考光られるもので，高分子溶液論 においてきわめて重要な量である。この量は外部の影響 が全くないような場に置かれた高分子鎖が平均的に示す 広がり (unperturbed chain dimension) に関係する量 でこれは分子鎖を構成するすべての各種ボンドのボン ド長, ボンド角, 一重結合のまわりの内部回転ポテンシャ ルなならびにすべての非結合原子 (団) 間のポテンシャ ル（ファン・デル・ワールス相互作用，静電的相互作用 など）によって与光られ，それらの分子パラメーターは 当然低分子で得られた知見をもとにしている。特性比か らわれわれは長い分子に特徵的な鎖自体の屈曲性の程 度を分子構造に立脚して知ることができるわけである。

以上は外部影響のない場に执かれた鎖に関するもので あるが実際の溶液ではこれに溶媒が加わる。すなわち，

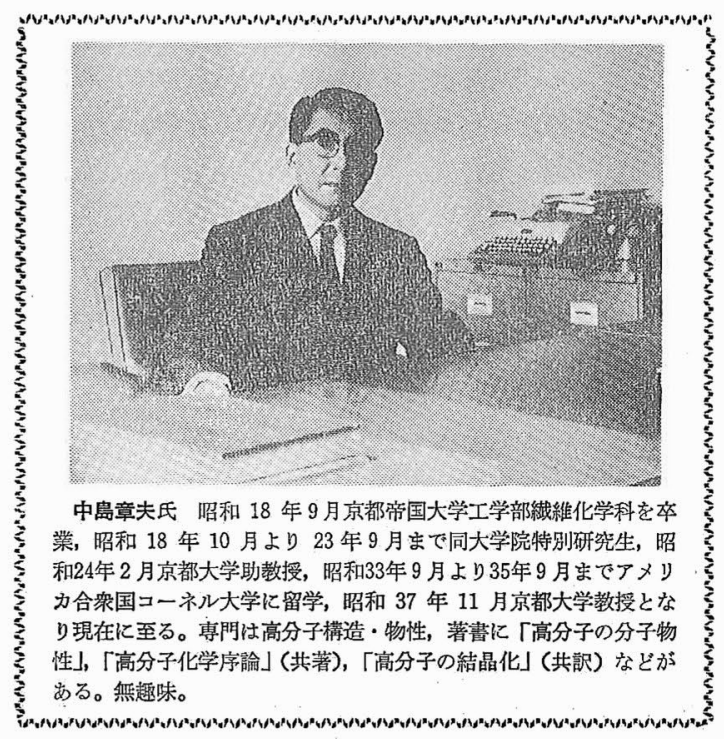

[268]
溶媒と高分子の相互作用が考慮されねね゙ならないわけで ある。良溶媒中で鎖は上述の理想系に猢忷るよりも広が ろうとするであうらし，悪溶媒中では縮まうらとするで あろう。ここで問題になるのは実験的に理想系を現出さ せることである。Flory は第2ビリアル係数が0になるよ うな特定の溶媒の特定の温度でこの理想系が達成される こと,またこの条件は特定の溶媒系で分子量無限大に外 择された高温臨界共溶温度 (upper critical solution temperature）に相当することを指摘し，これを $\Theta$ 点 (あるいは Flory 点) と呼んでいるが, $\Theta$ 点での鎖の広が り $\left\langle R_{0}{ }^{2}>\right.$ を基準にとって一般溶液中での広がり $<R^{2}>$ を $\alpha^{2}=<R^{2}>/<R_{0}{ }^{2}>$ の形で表わすと $\alpha^{2}$ によって溶

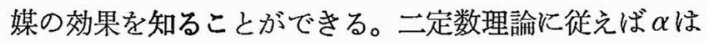
排除体積パラメーター $z$ (後出) のみの関数で与兄られ る。排除体積効果については過去 10 年間に倉田, 藤 田, 山川, Flory, Stockmayer, Fixman その他の人 たちによって多くの論議が重ねられた。

過剩体積 (excess volume) や低温蹦界共溶温度 (lower critical solution temperature) などの問題と 関連して最近，高分子液体ならびに溶液の状態方程式が 論議しだされた。鎖の屈曲性（剛直性）など高分子性の とり入れ方が問題であうう。

現在までのところ, 屈曲性の線状非電解質単独重合体 については, 希薄溶液論はわれわれに注ば满足な分子論 的解答を与えてくれるが，屈曲性の枝分かれ重合体や共 重合体, さらに電解質重合体, ならびに半屈曲性高分子 や用宜高分子については，分子の characterization の 問題とも関連しまだ未解決の問題も多い。

いささか前置きが長くなったが以下にこれらにひいて 紙面の許される範囲で記述することにする。

\section{2. 高分子鎖の形態}

前述したように，外部の影響の全くない場に一つの分 子が置かれたときの分子のとりうる形態を考兄てみよ 5。第 1 図にェタン, $n$-ブタン, $n$-ペンタン, 抢よび炭 素数が nのポりメチレンと示した。一重結合のまわり では内部回転が許さ机るから回転のポテンシャル極小を $\mathrm{T}\left(\right.$ トランス, 内部回枟角 $\left.\varphi=0^{\circ}\right), \mathrm{G}($ ゴーシュ, $\varphi=$ $\left.+120^{\circ}\right), \mathrm{G}^{\prime}\left(\right.$ ゴーシュ, $\left.\varphi=-120^{\circ}\right)$ の三つとすると, 区別しうる鎖の 形態の数はエタンで $1, n$-ブタンで 3 , $n$-ペンタンで $3^{2}$, 炭素数が $n$ のポリメチレンで $3^{n-3}$ 通 りといらように，高分子性は形態数がきわめて大きいと いらことに反映してくる。n-ブタンでは $\mathrm{C}_{(4)}$ が $\mathrm{C}_{(1)}$ に 対して G.あるいは $\mathrm{G}^{\prime}$ の位置にきても $\mathrm{C}_{(1)}$.についた $\mathrm{H}$ と $\mathrm{C}_{(4)}$ についたH原子の間に衝突は起こらないが, $n$-ペ

「高分子」 1971 
<smiles>OC(=[GeH2])C(O)O</smiles>

エタン<smiles>O=C(O)OC(=O)C(=O)O</smiles>

nーブタン

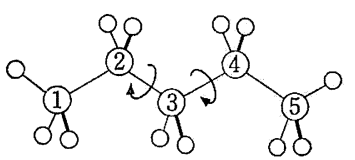

(a)

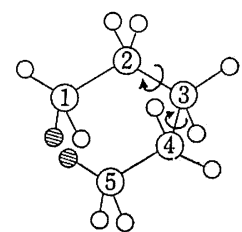

(b) nーペンタン

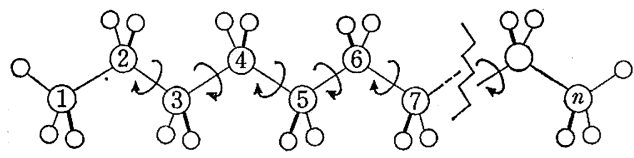

ポリメチレン

第 1 図

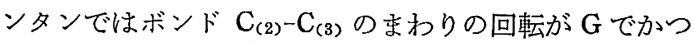
ボンド $\mathrm{C}_{(3)}-\mathrm{C}_{(4)}$ の亲わりの回転が $\mathrm{G}^{\prime}$ であるような配 座 ( $G, G^{\prime}$ 配座, 図の $(b)$ 参照),ならびに $G^{\prime} G$ 配座 では $\mathrm{C}_{(1)}$ についた $\mathrm{H}$ と $\mathrm{C}_{(5)}$ についた $\mathrm{H}$ 原子との間 の距離がきわめて接近し，このような配座はエネルギー 的にきわめて出現しにくいものになる。この効果はペン タン効果と呼ばれ，n-ペンタンの場合この効果のため分 子のとりうる形態数は二つ少なくなり，分子鎖の末端間 距離の平均はそれだけ大きくなることになる。nーブタ ン，nーペンタンに打ける三つの C-C ボンド，四つの C-Cボンドを隔てた相互作用はとれぞれ 3 ボンド相互作 用，および 4 ボンド相互作用と呼ばれているが，長い分 子鎖の非摂動の平均的な広がりを求める場合，4 ボンド 相互作用をでが考慮され，それ以上高次の相互作用は無 視してさしつかえない。

高分子鎖の非摂動の広がりは鎖端間距離の 2 乘 $R_{0}{ }^{2}$ の,すべての可能な形態に関する平均 $<R_{0}^{2}>$ で定義さ れるが，分子鎖がボンド長 $b$ の $N$ 個のボンドよりなり たっている場合， $i$ 番目のボンドベクトルを $\boldsymbol{b}_{i}$ とする
と $<R_{0}^{2}>$ は次式で与えられる。

$$
\left.<R_{0}^{2}\right\rangle=N b^{2}+2 \sum_{i<j}^{N}<\boldsymbol{b}_{i} \cdot \boldsymbol{b}_{j}>
$$

長い分子鎖の場合，高分子性はスカラー積 $\boldsymbol{b}_{i} \cdot \boldsymbol{b}_{j}$ の平 均の問題といらことになるわけで，これはボンド長 $b$, ボンド角 $\theta$,ならびに $\mathrm{T}, \mathrm{G}, \mathrm{G}^{\prime}$ などの各配座(いいか党 ると内部回転角 $\varphi$ ）に刘するポテンシャルェネルギー （各配座の統計的な重みと表現してもよい）関数として処 理される。低分子化合物に関する知見からボンド長 $b$ や ボンド角 $\theta$ は，たと亲ばボンド C-Cに対して $b=1.54 \AA$, ボンド角 $\angle \mathrm{C}-\mathrm{C}-\mathrm{C}$ について $\theta=109^{\circ} 28^{\prime}$ のように数值 が知られているから，結局 3 ボンド相互作用， 4 ボンド 相互作用に関するポテンシャル関数がわかれば上述の平 均化が行なえるわけである。各種高分子に関する特性比 の計算については成書1) を參考にされたいが，二三の 結果をとりだしてみると第1表のようである。

第 1 表 鎖状高分子の特性比 $<R_{0}{ }^{2}>/ N b^{2}$

\begin{tabular}{|c|c|c|c|c|}
\hline \multirow{2}{*}{ 高 分 子 } & \multicolumn{2}{|c|}{$<R_{0}^{2}>/ N b^{2}$} & \multicolumn{2}{|c|}{$\begin{aligned} d \ln < & <R_{0}^{2}>/ d T \\
& \times 10^{3}\end{aligned}$} \\
\hline & 実测值 & 理論值 & 実測值 & 理論値 \\
\hline $\begin{array}{l}\text { ポリエチレン } \\
\text { (線状) } \\
\text { ポリプロピレン }\end{array}$ & $\begin{array}{c}6.80^{6)} \\
\left(163.8^{\circ} \mathrm{C}\right)\end{array}$ & $\begin{array}{c}6.75^{7)} \\
\left(160^{\circ} \mathrm{C}\right)\end{array}$ & $-1.21^{6)}$ & $-1.16^{7)}$ \\
\hline$i s o t\left(p_{r}=0.95\right)$ & $\begin{array}{c}\left.6.35^{8}\right) \\
\left(125.1^{\circ} \mathrm{C}\right)\end{array}$ & & $-1.6^{9)}$ & \\
\hline$i \operatorname{sot}\left(p_{r}=1\right)$ & & $8.5^{10)}$ & & $-1.9^{10\rangle}$ \\
\hline $\operatorname{synd}\left(p_{r}=0\right)$ & & $13^{10)}$ & & $-0.1^{103}$ \\
\hline $\begin{array}{c}\text { ポリイソプレ } \\
\text { ソ33 }\end{array}$ & & & & \\
\hline trans & 7.35 & & -0.3 & \\
\hline$c i s$ & 4.7 & 5.2 & +0.4 & +0.2 \\
\hline
\end{tabular}

ポりエチレン（線状）は分子構造からみて最も基本的 なポりマーであり，n-ブタン, $n$-ペンタンで知られるポ テンシャル関数を用い，各ボンドのまわりの回転が隣接 するボンドのまわりの回転と相関すると考光て算出され た特性比およびその温度傾斜は実測值とよい一致を示す ことが明らかにされた。ポリプロピレンの場合は分子鎖 中に淤る単量体単位の立体構造的配置，いいかえると 立体規則性が問題になり，モデル低分子としては $2,4-シ ゙$ メチルペンタンがあげられる。鎖中に括けるアインタク チック単位の出現確率を $p_{r}$ とすると，表から明らかな 上らた isot 分子 $\left(p_{r}=1\right)$ で $\left.<R_{0}^{2}\right\rangle / N b^{2}=8.5$, synd 分子 $\left(p_{r}=0\right)$ で $<R_{0}{ }^{2}>/ N b^{2}=13$ といらように特性比 が立体規則柾造に著しく依存することがわかる。第 2 図 はポリプロピレン $\left(\mathrm{R}=\mathrm{CH}_{3}\right)$ よりかさ高い側基 $\mathrm{R}=$ $\left(\mathrm{CH}_{2}\right)_{z}-\mathrm{CH}_{3}$ を含むポりマーの特性比の $p_{r}$ 依存性を安 


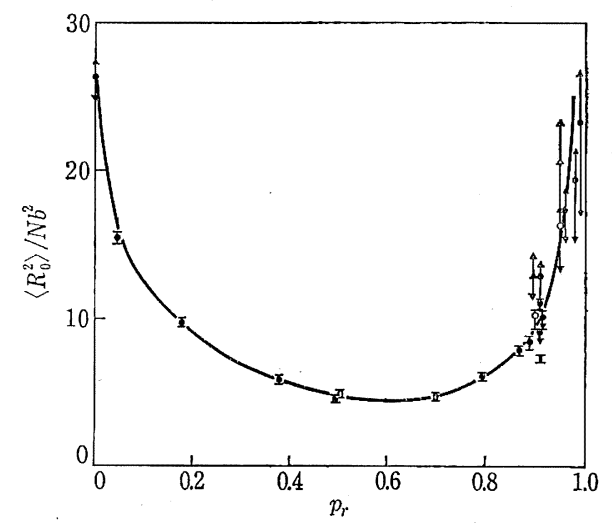

第 2 図側鎖が $\left(\mathrm{CH}_{2}\right)_{z}-\mathrm{CH}_{3}$ であるビニルポリ マ一の特性比の立体規則度による变化 ${ }^{10)}$

部 ${ }^{10)}$ の報告から引用した。この図より, 分子鎖の屈曲性 (剛直性) が側基のかさ高さならびに鎖の立体化学配置 (configuration) Kよって定まることが理解されよう。

二重結合のまわりでは内部回転は許されないが，二重 結合に関して transか cis かといらことは特性比に大き い影響を与学る。ポリイソプレンの trans-ポリマー(グ ッタペルカ) は $c i s$ ポリマー（天然ゴム）より大きい特 性比を示し, またその温度傾斜が両者で逆の符号にな る。

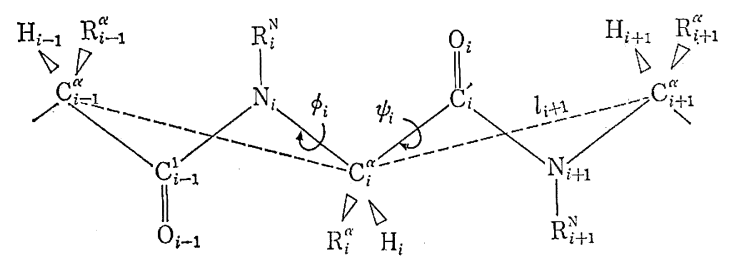

第 3 図 ポリペプチド鎖。 $\mathrm{R}^{\mathrm{N}}, \mathrm{R}^{\alpha}$ は置換基を示す

最後にもら少し複雑な分子の例としてポリペプチドを あげて括こう。第 3 図に示したよらに, くり返し単位中 の各ボンド長, 各ボンド的はいずれも異なるが, 相隣る $\mathrm{C}^{\alpha}$ 原子を結んだものを実質ボンドとし，その距離を $l$, また鎖を構成する実質ホホンドの数を $n$ として特性比は $\left\langle R_{0}{ }^{2}>\right| n l^{2}$ と表わされる。䇥者ら ${ }^{11)}$ は代表的な型の分 子としてポリグリシン，ポリームーアラニン，ポリ-N-グ リシン, ポリーN-メチル-L-アラニンを選び, それらの単 独重合体ならびに 2 成分共重合体, さらに立体規則性分 子としてポリ-D, L-アラニン, ポリ-N-メチル-D, L-アラ ニンなどについて特性比の理論計算を行なった。第 2

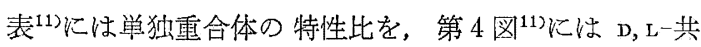
重合体の特性比のシークェンス確率 $p_{L}\left(p_{L}\right.$ が大きい汪ど L 単位のブロ.ック性が大きい) 依存性を示した。 D, L-共 重合ポリペプチドの調製は D-モノマー NCA と L-モノ
第 2 表 ポリペプチドの特性比 $<R_{0}{ }^{2}>/ n l^{2}$

\begin{tabular}{c|c|c}
\hline \hline \multirow{2}{*}{ 高 分 子 } & \multicolumn{2}{|c}{$<R_{0}{ }^{2}>/ n l^{2}$} \\
\cline { 2 - 3 } & 理諭值 & 実测值 \\
\hline ポリグリシン & 2.17 & \\
ポリ-L-アランン型 & 8.38 & 8.5 \\
ポリ-N-メチルグリシン & 2.97 & $1.8 \pm 0.2$ \\
ポリ-N-メチル-Lーフラニン & 0.58 & \\
\hline
\end{tabular}

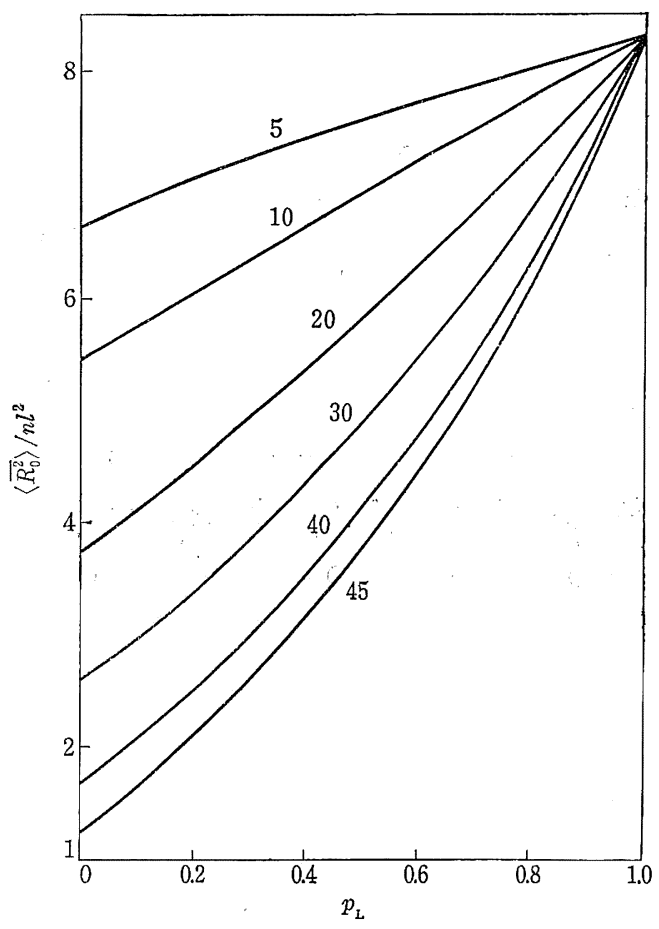

第 4 図 D, L-アラニン共重合ポリペプチドの特 性比とし体のシークェンス確率 $p_{L}$ の闒 係, 図中の数字は L 体の含率 (モル\%) を示す。

マーNCA の反応によって行なわれるという点でビニル モノマーの立体特異性重合と異なり，D，L-共重合ポリペ プチドのコンホメーションの検討は重合機構とも関連し て重要であるが，未解決の問題がきわめて多い。

\section{3. 高分子融体ならびに溶液の分子論}

対応状態の原理 (principle of corresponding state) が実存気体にあてはまることは古くから知られた事実で あるが Pitzer (1939)，拈よび Guggenheim (1945) は 球状分子の液体に対してもこの原理が適合することを明 らかにした。すなわち, 還元圧力, 還元体積, 還元温度 をそれどれ $\tilde{P}, \tilde{V}, \tilde{T}$ で表示すると状態方程式は還元量 
娄用い

$$
\tilde{P}=\tilde{P}(\tilde{T}, \tilde{V})
$$

で表示される。鎖状高分子液体に対する理諭的取扱は

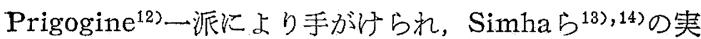
験によって高分子に対しても対応状態の原理がなりたつ ことが確かめられた。Prigogineはさらに高分子液体(純 体）のみならず溶液（混合体）にも理論を拡張し，溶液 のモル熱力学量が対応状態の原理に従らことを指摘し た。その後この方面の研究は Flory ら ${ }^{15), 16)}$, Patterson ら ${ }^{17}$ によっても進展の途上にある。Prigogine の細 胞理論 (cell theory) は, 高分子溶液は溶媒と高分子そ れぞれの個性を還元変数のパラメーターを通じて反映さ せるといら点で，たと党ば正則溶液理論から出発する高 分子溶液論や，溶媒を高分子の置かれるふ九い気とみな して高分子を不完全気体論から取り扱扣うとする高分子 希薄溶液論と異なっている。希薄溶液で山混合による体 積変化は然視できる程度であろうが，それでも体樍変 化があるということが例外ではなく，むしろないという ことが例外であるわけで，細胞理諭から出発する溶液諭 は，当然のことであるがこの体積変化を説明するのであ る。この領域の研究は溶液論の今後の進路の一つを与克 るものとして期待されるところである。ここではこの理 論烧行る高分子性の取入れ方について簡単にふれてお こう。

細胞理論によれば，r個のセグメントよりなる鎖状高 分子を $N$ 個含む系の状態和 $Z$ は次式で与兄られる。

$$
Z=G \psi^{r_{N}} \exp \left(E_{0} / k T\right)
$$

$G$ は組合せ因子， $\psi$ は細胞中に护ける一つのセグメン トの状態和， $E_{0}$ はすべてのセグメントが 細胞の中心に ある時の分子間ポテンシャルェネルギーである。問題の 一つは $\psi, E_{0}$ をどのような形で導入するかといらこと であるが，細胞中に晾けるセグメントの運動が井戸形ポ テンシャルであるとすると

$$
\psi=[b(a-\sigma)]^{3 c}
$$

また， $E_{0}$ は Lennard-Jones 形とすると

$$
E_{0}=(1 / 2) N r q z \varepsilon *\left[A\left(v^{*} / v\right)^{4}-B\left(v^{*} / v\right)^{2}\right],
$$

van der Waals 形相互作用を仮定すると

$$
E_{0} \propto-(1 / 2) \operatorname{Nrqz}(1 / v)
$$

のように書くことができる。上式で $b$ は幾何係数， $a$ は

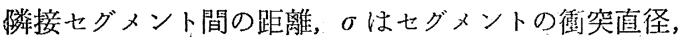
きははセグメントの接触対あたりの分子間エネルギー， v拈よび $v^{*}$ はセグメントあたりの全体積および正味 の体積で，六方稒密格子の場合怯配位数 $z=12$ で $A=$ $1,011, B=2,409, a^{3}=2^{1 / 2}, \sigma^{3}=v^{*}$ である。また， $q z$ 奴グメントあたりの分子間最近接座席の数, $3 c$ はセ
グメントあたりの外部自由度の数である。（4）拈よび （5）式を用いる場合には（3）式上り，状態方程式は 還元変数により

$$
\begin{aligned}
\tilde{P} \tilde{V} / \tilde{T}=\left(1-2^{-1 / 6} \tilde{V}^{-1 / 3}\right)^{-1} & \\
& +\left(2 \tilde{V}^{-2} / \widetilde{T}\right)\left(A \tilde{V}^{-2}-B / 2\right)
\end{aligned}
$$

低圧 $(P \sim 0)$ ではさらに,

$$
\tilde{T}=\left(1-2^{-1 / 6} \tilde{V}^{-1 / 3}\right)\left(B \tilde{V}^{-2}-2 A \tilde{V}^{-1}\right)
$$

ただし $\tilde{T}=T c k /\left(q z \varepsilon^{*}\right), \quad \tilde{V}=v / v^{*}$

となる。すなわち高分子液体の熱力学量は $c, q z \varepsilon^{*}, v^{*}$ の 三つのパラメーターで特徽づケられることになる。すな わち，高分子性はこれらのパラメーターが $r$ のどのよ らな関数で与兄られるかということになる。Prigogine ら ${ }^{18)}$ に上机ばーつの $r$-量体の外部自由度 $3 \mathrm{cr}$ は屈曲 性の $r$-量体 $(r \geq 2)$ では $3 c r=2 r+1$, 半屈曲性の $r-$ 量体では $3 c r=r+3$, 剛直性の $r$-量体では $3 c r=6$ と

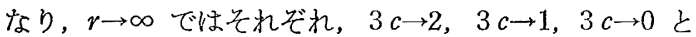
なることが指摘される。これを低分子 (単量体) 液体と 此較すると低分子の場合は内部自由度は 0 でまた $r=1$

\begin{tabular}{|c|c|c|c|}
\hline 質 & $\begin{array}{c}v^{*} \\
\left(10^{-24} \mathrm{~cm}^{3}\right)\end{array}$ & $\begin{array}{c}q 2 \varepsilon^{*} \\
\left(10^{-16} \mathrm{erg}\right)\end{array}$ & $3 c$ \\
\hline 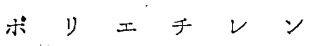 & 25.74 & 1160 & 0.50 \\
\hline ポリジチルシロキサン & 55.25 & 1990 & 1.38 \\
\hline ボリエチレンオキシド & 19.64 & 1270 & 0.61 \\
\hline ホリス チ レ ン & 78.43 & 4360 & 1.87 \\
\hline $\begin{array}{c}\text { ボリテトラフルオルエチ } \\
\text { レン }\end{array}$ & 36.61 & 1390 & 0.81 \\
\hline ル & 39.48 & 1984.4 & 3 \\
\hline × & 55.61 & 2455.0 & 3 \\
\hline
\end{tabular}
であるから $3 c r=3 r$ 上り $3 c=3$ となる。第 3 表には 各種ポりマーに対する上記の三つのパラメーターの実測 結果をあげ，あわせてアルゴン，メタンの結果とも比較 した。ここではセグメントとして単量体単位がとられて いる。

第 3 表 セグメントパラメーター $v^{*}, q z \varepsilon^{*}, c$ の実测値 $\left.{ }^{13)}, 14\right)$

この上うにcは分子の屈曲性の尺度211 とみなされる

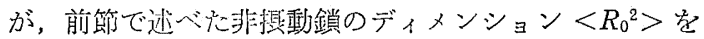
尺度とした屈曲性とは必ずも並行的ではない。

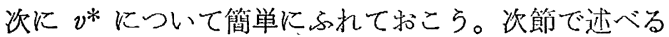
セグメントあたりの排除体積，すなわち 2 体クラスター 積分 $\beta$ は近似的に $\beta=\left(4 \pi b^{3} / 3\right)[1-(\Theta / T)]$ と書ける が，七グメントを単量体単位とすると $b$ は球と考えた 単量体単位の直径に等しく, ここでの記号で示せば $b^{3}=$ $\sigma^{3}=v^{*}$ となる。山川 $\left.{ }^{19}\right)$ は希薄溶液での 実験をもとにポ 
リスチレンートルェン $\left(30^{\circ} \mathrm{C}\right)$ 系で $\beta=23.7 \times 10^{-24} \mathrm{~cm}^{3}$ と見積っているが，この系で $\Theta=160^{\circ} \mathrm{K}\left(\mathrm{Fox}^{20)}\right)$ を採 用すると $v^{*}=78.43 \times 10^{-24} \mathrm{~cm}^{3}$ (第 3 韯の值), $T=303^{\circ} \mathrm{K}$ から $\beta=164.5 \times 10^{-24} \mathrm{~cm}^{3}$ となる。このへんの検討も今 後の問題であるう。

\section{4. 溶液物性と高分子の構造}

\section{4-1. 屈曲性高分子}

\section{4-1-1. 線状単独重合体}

高分子溶液の浸透圧は高分子濃度の低い領域において も，一般に低分子溶液のそれと比べて著しい濃度依存性 を示すことが古くから知られている。この挙動が分子鎖 の鎖長の增加に伴われるェントロピー効果に基くもので あることを指摘し，高分子溶液の熱力学的性質をはじめ て定量化したのは Flory と Huggins (1942) である。 溶媒と溶質が混合する際，混合自由エネルギーは混合熱 と混合エントロピーの寄与の和として与えられるが，混 合熱を 0 とする場合 (無熱溶液), Flory-Huggins の格 子理論は次式により溶質の鎖長 $r$ ，溶質濃度（体積分率 を $v_{2}$ ，モル分率を $x_{2}$ とする) の関数として溶媒の活 量 $a_{1}$ (いいかえると混合自由エネルギー) を与兄る。

$$
\begin{aligned}
\ln a_{1}= & \ln v_{1}+\left(1-r^{-1}\right) v_{2} \\
= & \ln \left[\left(1-x_{2}\right) /\left(1-x_{2}+r x_{2}\right)\right] \\
& \quad+\left(1-r^{-1}\right) r x_{2} /\left(1-x_{2}+r x_{2}\right)
\end{aligned}
$$

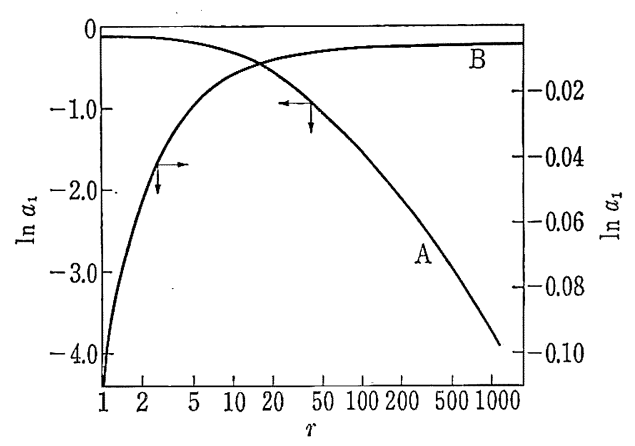

$\mathrm{A}$ はモル分率 $x_{2}=0.1$ (一定), B は体積分率 $v_{2}=0.1$ (一定) の場合の曲線

第 5 図 無熱溶液の溶媒活量 $a_{1}$ と溶質の鎖長 $r$ の関係

第 5 図にはモル分率 $\aleph_{2}=0.1$ (一定)，ならびに 体積 分率 $v_{2}=0.1$ (一定) の場合の溶媒活量の鎖長依存性を 示したが，鎖長 $r=1$ から $r=\infty$ の全域で $\ln a_{1}$ は連 続的徐々に变化していることがわかる。すなわら高分 子溶液浸透圧の特性は鎖長 $r$ を考慮することにより低分 子 $(r=1)$ 理想溶液のそれと連続的に理解寸ることがで きるのである。
以上は浱度の広い範囲に関するモデル系に対する結果 であるが，単独にとり出された分子鎖の構造を検討する ためには極限希薄溶液ないし希薄溶液の溶液物性が問題 となる。2．で屈曲性分子鎖の “理想状態”に拈ける広 がり $<R_{0}{ }^{2}>$ について述べたが，実際の溶液中では溶 媒の良悪によって鎖の広がり $<R^{2}>$ は $<R_{0}^{2}>$ より大 きくなったり，小さくなったりするわけである。鎖の広 がり $<R^{2}>$ の評価ということは, 浸透圧の第 2 ビリア ル係数, 高分子溶液の光散乱, 高分子溶液極限粘度数な どを諭議するうえできわめて重要である。

三つないし四つのボンドを隔てた相互作用が $<R_{0}{ }^{2}>$ の計算に取り入れられることはすでに述べたとおりであ るが，之れ以上の数のボンドを隔てた遠距離分子鎖部分 の相互作用のため良溶媒中で分子鎖の $<R^{2}>$ は $<R_{0}{ }^{2}>$ より大きくなる。鎖の要素をセグメントと呼んでおく と, 遠距離相互作用のためにセグメントが互に排除し合 い，その結果として良溶媒中で広がりが大となると考兄 るのである。

分子鎖中で遠距離にある二つのセグメントを考光，そ の距離を $R$ ，セグメント間のポテンシャルエネルギーを $v(R)$ とすると

$$
\beta=\int_{0}^{\infty}[1-\exp \{-v(R) / k T\}] 4 \pi R^{2} d R
$$

で定義される 2 体クラスター積分 $\beta$ は，一つのセグメン トが存在するためいま一つのセグメントの中心がはいり 込めない体積,すなわちセグメントの排除体積を与える。 こうすると，溶媒とセグメントの相互作用は $v(R)$ の中 で考虑されることになる。一方，分子鎖全体の平均的な 広がり $<R^{2}>$ は

$$
<R^{2}>=\alpha^{2}<R_{0}^{2}>
$$

として，膨張係数 $\alpha$ を用い $<R_{0}{ }^{2}>$ から分離する。 $<R_{0}{ }^{2}>$ の数值は前述したように分子パラメーターで計 算されるが，これはさらにここで考えているセグメント の長さ $a$, お上び数 $n$ でもって， $<R_{0}{ }^{2}>=n a^{2}$ として 与えられる。最近の排除体積に関する二定数理諭に従光 ば排除体積パラメーター $z$ 学

$$
z=\left(3 / 2 \pi a^{2}\right)^{3 / 2} \beta n^{1 / 2}
$$

と定義すると，膨張係数 $\alpha$ は $z$ のみの関数になる。す なわち，実在溶液中に淤子る分子鎖の広がり $<R^{2}>$ が 鎖長 $n$, セグメントのディメンション $a$, 溶媒効果 $\beta$ の 関数として説明できるのである。以上は分子鎖内の排除 体積効果であるが，分子鎖間の排除体積の最も次数の低 いものは第 2 ビリアル倸数 $A_{2}$ である。 $A_{2}$ についても 二定数理論構成の枠内で矛盾のない結果が導かれてい る。しかしながら， $\alpha$ および $A_{2}$ の $z$ 依存性のあり方 
については各理論の間になお議論の余地が残されてい

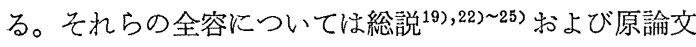
を参照されたい。

次にふれて和かねばならないのは溶液の極限粘度数

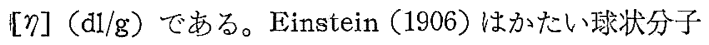
が液体中に㢡濁する場合， $[\eta]=0.025 \varphi$ ( $\varphi$ は分子の 比容）が成立すること，いいかえると［ク］が溶質の分 子量 $M$ によらないことを指摘しているが，桜田ら ${ }^{26)}$ (1933) はグルコースペンタアセテートのような低分子 の各種溶媒系でこの関係が成立することを報告してい る。屈曲性高分子鎖の [ク] と分子量 $M$ の関係はその 後 Staudinger，桜田らによって精力的に研究され， 1940 年には桜田 ${ }^{27)}$, Mark, Houwink により独立に

$$
[\eta]=K M^{a}(0.5 \leqq a \leqq 1)
$$

の関係が典型的な高分子の領域で成立することが指摘さ れた。

屈曲性分子鎖の [ク] を論議するに際して問題となる のは素抜け效果（流体力学的相互作用）と前述の排除体 積効果である。Flory は排除体積效果のない系, すなわ ち $\Theta$ 溶媒系での実験結果から

$$
[\eta]_{\theta}=K_{\theta} M^{0.5}
$$

を得，係数の検討からこの場合に素拔け効果が全くない といら重要な結論を出した。良溶媒系での素拔効果に ついてはな捈討の余地が残されているが屈曲性分子の 場合，良溶㷊系についても非素抜けであろらとする見解 が現在のところ優勢である。排除体積効果を考慮した理 論 $^{28)}$ は次の形に集約される( $B$ は $\beta$ の関数)。

$$
[\eta]=K_{0} M^{0.5}+B M
$$

この式によれば(15) 式の $a$ は $M$ の小さいところ,あ るいは $\Theta$ 溶媒では $a=0.5$ で, $M$ の増加あるいは溶媒

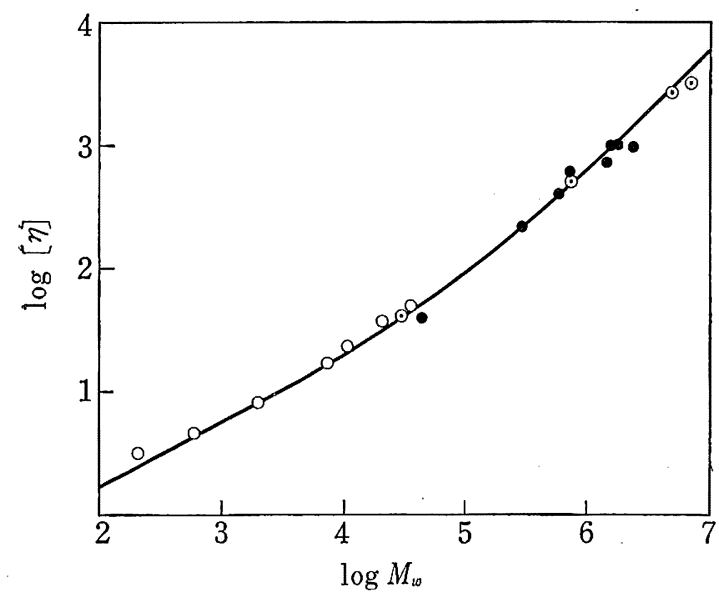

第 6 図 ポリエチレンオキシドー水 $\left(30^{\circ} \mathrm{C}\right)$ 系の極 限粘度数と分子量の関係
が良好になるにつれて $a=1$ に近ら゙くことが示唆され る。第 6 図 ${ }^{29}$ には $M_{w} \doteqdot 250$ から $M_{w} \doteqdot 5,500,000$ まで の広い分子量䉓团での実験結果を示したがこの結 果は

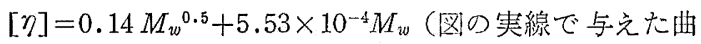
線)で無理なく説明される。

\section{4-1-2, 線状共重合体}

共重合体の分子構造は分子量, 分子鎖中にお汸る成分 モノマーの含率ならびに配列様式，立体規則性によって 特徵づケられこれは重合の機構と密接な関係があるこ とはいらまでもない。特にモノマーの配列様式といらこ とに着目すると, 交互共重合体, ランダム共重合体, ブ ロック共重合体に大別さ机る。共重合体溶液について まず問題となるのが $\Theta$ 点の把握である。稲垣，小高 ら 24),30) 32) はスチレンーメタクリル酸メチル系の上部三 つの型の共重合体について詳細な検討を行ない，それぞ れの型について $\Theta$ 点を見出し， $\Theta$ 点では分子鎖間の overa11 の排除体積は一応消えているとしている。分子 鎖内の排除体積効果についてはさらに [ク］と分子量の 関係を調ベ，交互およびランダム共重合体では分子鎖は ほぼランダム・フライト的であることを指摘している。 この結果は単独重合体で述べた二定数理論が，これらの 型の共重合体に対しても適用できるといらことを示すも のである。二定数理論の適用に执いて分子鎖をセグメン トに分割することが問題となるが，単纠重合体ではすべ ての単量体単位が等価であるから問題はなく，交互重合 全体では相繁る二つの単量体単位をまとめて考えればよ い。しかしながらブロック性の増大とともにこのような 模型は無效となる。最も典型的なブロック共重合体は成 分モノマーの含率が等しい A-B 型ブロック共重合体で ある。この種の共重合体はAおよびB成分に対しいずれ も良溶媒であるよらな溶媒中では第 7 図（a）に示した ような形態をとるであろらし，また一方の溶媒に対し良 溶媒, 他方の溶媒に対し悪溶媒として作用するような溶 媒中では第 7 図（b）のような形態となるであろう。A 䂆よびBのセグメントはそれぞれ同種のもの同志で集ろ うとするから，いわゆる分子内相分離が起こりやすい。

Stockmayer ${ }^{33}$ はA-B型ブロック共重合体の非摂動

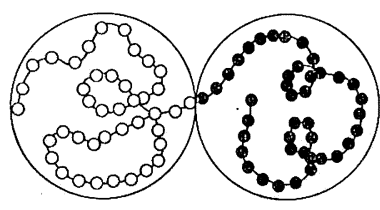

(a)

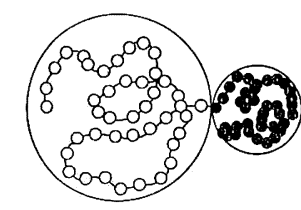

(b)
第 7 図 A-B 型ブロックポリマーの良溶媒 (a), 選択的溶媒 (b) 中での形態 
鎖のディメンション（慣性半径の 2 乗平均） $<S_{0}{ }^{2}>/ M_{w}$ が親ポリマーのそれらと加成性的関係すなわら

$$
\begin{aligned}
<S_{0}{ }^{2}>/ M_{w}=\varkappa_{\mathrm{A}}[ & \left.<S_{0}{ }^{2}>/ M_{w]}\right]_{\mathrm{A}} \\
& +\varkappa_{\mathrm{B}}\left[<S_{0}{ }^{2}>/ M_{w}\right]_{\mathrm{B}}
\end{aligned}
$$

の関倸にあるとしている( $M_{w}$ は重量平均分子量, $x_{A}$ は成分 $\mathrm{A} の$ 重量分率) が，稲垣ら ${ }^{32}$ はスチレンーメタク リル酸メチルの A-B 型共重合体でこの関嗦が成立し, またランダム共重合体ではこの直線関係より若千大きく なることを報告している。さらに稲垣らは良溶媒系での 鎖の広がりが同じ組成，同一分子量のもので比較してラ ンダム共重合体の方がA-B型ブロック些重合体より大き く，これは非掑動鎖ディメンションに加えるに排除体積 の效果が前者の共重合体で大さいことによると説明して いる。ブロック共重合体についてはミクロ相分離の問題 も最近注目さ机ている52)。

\section{4-1-3. 枝分かれ重合体}

高压法ポリェチレンが枝分か机分子であることは古く

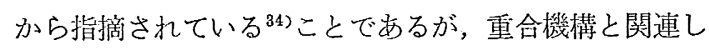
て種々の高分子で短鎖分岐や長鎖分岐の存在が知られて いる。分彼の存在は材料の物性に大きい影響を与兄る， 枝分かれ高分子を特徴づけには，分子量ならびに分子 量分布，枝の数と長さ，ならびにそれらの分布，分岐の 型, さらにグラフト共重合体の場合には組成に関する因 子が必要である。分岐の型は主として高分子の生成機棈 と関連して推定され，基本型として櫛型，カスケード型， 統計的分岐型，星型などがあげられる。

希薄溶液物性を分岥パラメーター之関連づけることに よって溶液論的に分岐度を評価することが可能なはずで ある。ここで実験的に亲ず問題になるのは分子量分布の 効果と枝分かれの効果を分離することである。阿部ら は両者の効果の分離にカラム分別が有効であることを報 告している。したがって，分子量が異なる一連の同型枝 分かれ分子 (単分散状) を試料として理論の検討が可能 になるわけである。

理論的には上述の各型の枝分かれ分子の模型について $\Theta$ 溶媒中での平均 2 乘慣性半径 $\left\langle S_{0}{ }^{2}\right\rangle_{b}$ を同一分子量 の線状高分子の平均 2 乗慣性半径 $\left\langle S_{0}{ }^{2}\right\rangle_{l}$ に対する比 として

$$
\left.g_{s}=\left\langle S_{0}{ }^{2}\right\rangle_{b} /<S_{0}{ }^{2}\right\rangle_{1}
$$

で与兄，gs が分岐パラメーターの関数として計算され ている。極限粘度数に関してはなだ㰾密な理諭は提出さ れていないが, $\Theta$ 溶媒中での枝分かれ高分子, 線状高分 子 (同一分子量で比較) の極限粘度数の比 $g_{\eta}$

$$
g_{\eta}=[\eta]_{\theta, b} /[\eta]_{\theta, l}
$$

が $g_{s}$ と次の関係にあることが指摘されている。

$$
g_{\eta} \approx g_{s}^{1 / 2}
$$

(21) 式の関係を用いると

$$
[\eta]_{0, b}=g_{s}{ }^{1 / 2} K_{\theta} M^{0.5}
$$

であるから $\Theta$ 点での $[\eta]_{\theta, b}$ と分子量の関倸を調べる ことによって分岐に刘する知見が得られるわけである。 また， $\Theta$ 点以外においても

$$
[\eta]_{b} /[\eta]_{l} \doteqdot g_{s}{ }^{1 / 2}
$$

の関係が近似的に成立することが知られている。これら

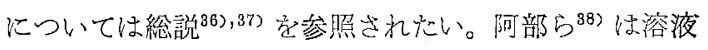
物性から長鎖分岐度を推定する方法を馀じ，これを各種 合成ゴムの長鎖分岐の定量に適用している。的最近, 倉田ら ${ }^{39}$ は分別を行ならことなしに溶液極限粘度数と GPC 溶出曲線だけから, 統計的枝分かれ高分子の分岐 度怙よび分子量分布を決定する方法る提案している。

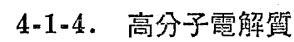

高分子電解質では高分子性のほか侧鎖についた電離 基のために電解質としての性質が珼われる。たと省い゙ポ リアクリル酸ナトリウムが解離すると $\mathrm{Na}^{+}$(対イオン)が 放出され高分子鎖には一-COO-(圆定イオン)が生ずる。解 離の程度は高分子の種頪, 溶媒の $\mathrm{pH}$, 高分子の濃度に著 しく依存するが固定イカン間にクーロンカが働くことに なる。非電解質の屈曲性鎖では鎖の広がりはらつう半径 数百 $\AA$ 程度であるが解離した電解質高分子で怡鎖要素の 間に非電解質鎖に和けるファン・デル・ワールスカのほ か炕クロン力すなわち電気的な力が加わるわけであ る。前者は要素間距離の -7 乗に比例する力であるに比 して，後者は距離の -2 乘に比例する力であり前者より はるかに遠方にあで作用を及洔すものである。分子鎖に 結合された固定イオンが電気的に同じ符号のものである と，固定イオン間のクーロン力は哌力となりファン・デ ル・ワールスカル優先し，この分子鎖は熱運動の効果と鈎 り合うところまで膨張するであろう。固定イオンの数の 增加とともに厉力は增大し，分子鎖の広がりはなすをす 增大し，遂には分子鎖は十分に引き伸ばされた棒状の形 にまでなることが考觉られる。言葉をかえていらとクー ロン斥力のために排除体積効果が著しく大であるわけで ある。次に高分子電解質水溶液に低分子添加塩が存在す る場合学考克てみよう。この場合には高分子固定イオン の采わりに低分子イオンが介在し，固定イオン間の斥力 が弱をり、そのため分子鎖の広がりが縮李ることになる。

このように長距離に働くクーロン力のため電解質高分 子溶液はまだ理諭的に完全に解明されたとはいえない。 鎖の広がり，第 2 ビリアル係数，極限粘度数などについ て非電解質高分子溶液のそれら之首尾一貫した理諭の完 成が望をれるわけで, Flory, Rice ら, Eisenberg ら, 
Alexandrowicz, 永沢一高橋, その他の研究がある。詳

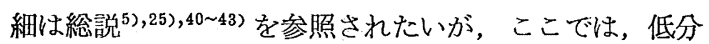
子塩添加系の 高分子電解質溶液極限粘度数 [ク] と分子 量 $M$ に関して高橋ら ${ }^{44}$ によって得られた特に注目すべ き結果について述べて抗こう。第 8 図は添加塩濃度が

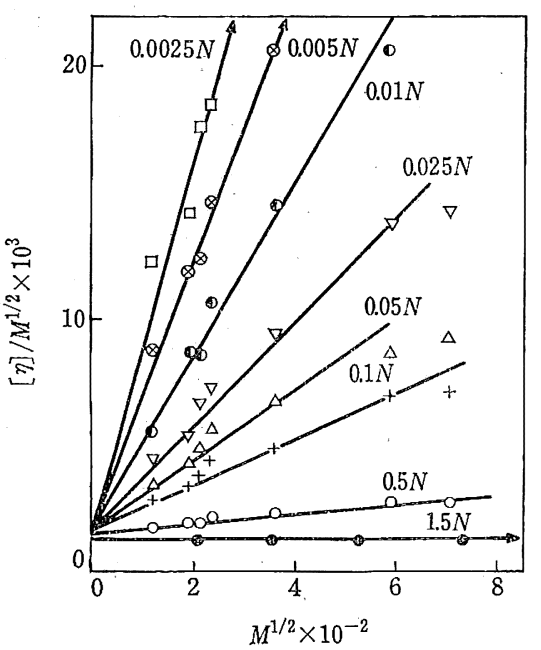

第 8 図 ポリアクリル酸ナトリウムの $\mathrm{NaBr}$ 水溶 液における [ク］と $M$ に関する Fixman プロット $\left(15^{\circ} \mathrm{C}\right)$. 図中の数子は $\mathrm{NaBr}$ 濃度

0.0025 から $1.5 \mathrm{~mol} / \mathrm{l}$ 市での場合について，(17) 式の

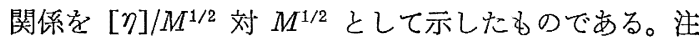
目すべきは分子量の高い領域では偏倚があるが，添加塩 濃度がかなり小さい領域すなわち電解質効果の存在する 領域に抢いても（17）式の関係がほぼ成立し，直線は注 ぼ一点に集まること，また低分子塩濃度が $1.5 \mathrm{~mol} / l$ で

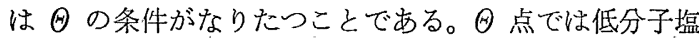
のしゃへい效果のため分子鎖は非電解質高分子のそれと 全く同じように非摂動鎖長を与え $[\eta]_{\theta}=K_{\theta} M^{1 / 2}$ の関係 が成立するわ斿である。

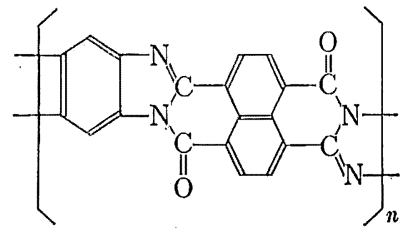

(a)

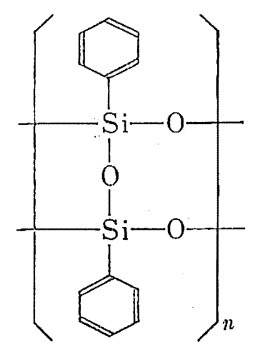

(b)
電離基を含む合成ポリペプチドの分子形態の問題や45) タンパク質の分子形態の変化に与兄る電離基の効果, ポ リイオンコンプレックスの形成やコアセルベーション46) など生体高分子の領域を含めて高分子電解質溶液論は将 来㱙残された問題がきわめて多い。

\section{4-2. 非屈曲性ならびに半屈曲性高分子}

\section{4-2-1. 非屈曲性重合体}

属曲性高分子では多かれ少なかれ分子骨格の一重結合 の京わりの内部回転のために分子は全体としてきわめて 多くの形態をとることができ，分子の広がりは光れらの 可能な形態に関する平均量として与えられることはすで に述べたとおりであるが，第 9 図に示したよらな分子の 骨格が環構造であるような高分子 [第9図（a)]，はし ご型高分子としてのcis-synd-polyphenylsilsequioxane (PTS) [第9図 (b)] p DNA [第9図 (c)], ポリ ペプチドの $\alpha$-ヘリックス[第 9 図 (d)]，さらに分子 内に多くの交叉結合を含む各種のタンパク質では内部回 転の可能性は皆無かあるい性きわ制約され，そのた め分子はかたいラセン棒，回転ダ円体，球など特定の形 をとって溶媒中に分散することができる。上述の例のう ち，ポリチペプドや DNA では分子内の水素結合が破壊 されるような条件では，いわゆるへリックスーコイル転 移を起こし分子鎖の属曲性は屈曲性分子鎖のそれとして 扱わ机るものになる。

回転名円体状の剛体分子の極限粘度数を分子の軸比々

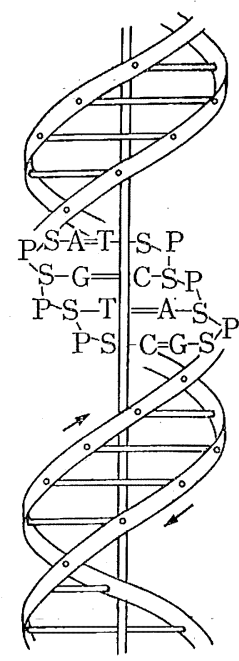

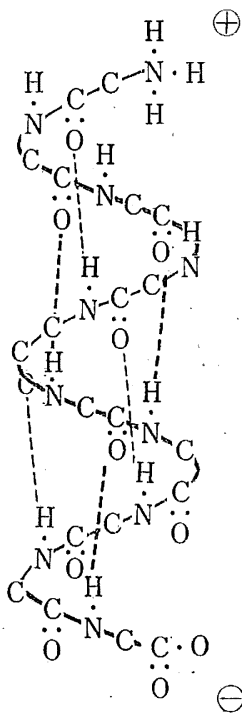

第 9 図 非屈曲性高分子の例 
関係つける試みはかなり古くからなされている(Simha， 1940)。棒状分子，球状分子，扁平分子は特別の場合に 相当するわけである。長軸と短軸の長さの比を $f$ で与え ると $f>100$ の条件で棒状分子に対し

$[\eta] \propto f^{1.81}$

となる。 $f$ は分子量 $M$ に比例するわ忷であるが, 実験的 にはポリペプチドの $\alpha$-ヘリックスについて $[\eta]=K M^{a}$ の指数 $a$ として $a \doteqdot 2$ の值が 得られている。屈曲性分 子の場合の $0.5 \leq \mathrm{a} \leq 1$ と比して棒状分子では [ク]の $M$ 依存性が著しく大さい。

第 9 図の（a）や（b）の型の分子についてはまだ確 定的な情報は得られていないが，PTS に関する実験結 果 $a=0.916$ を素抜け効果によるものと推定している人

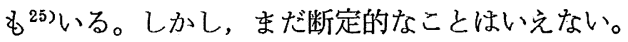

溶液の熱力学的性質については棒状分子に対する Flory ${ }^{472}$ の理諭が有名である。棒状分子をマッチの軸に たとえると無限大の体積中ではマッチ軸を無秩序に配置 することがでさるが 体樍の減少（すなわち濃度の增加） とともにマッチ軸はちょらどマッチ箱に入れたマッチ軸 のように並行に配置された方が自由エネルギー的に安定 となる。第 10 図 $^{48}$ には軸比 $x$ が 150 および 350 の 棒状分子の相図を熱力学的相互作用パラメーター $\chi_{1}\left(\chi_{1}\right.$ の增加は温度の低下に対応する）と高分子濃度 $v_{2}$ (体積 分率）の間の関係で与えた。それぞれ二つの曲線よりも 上の部分では相分離が起こる。左側の曲線より下の部分

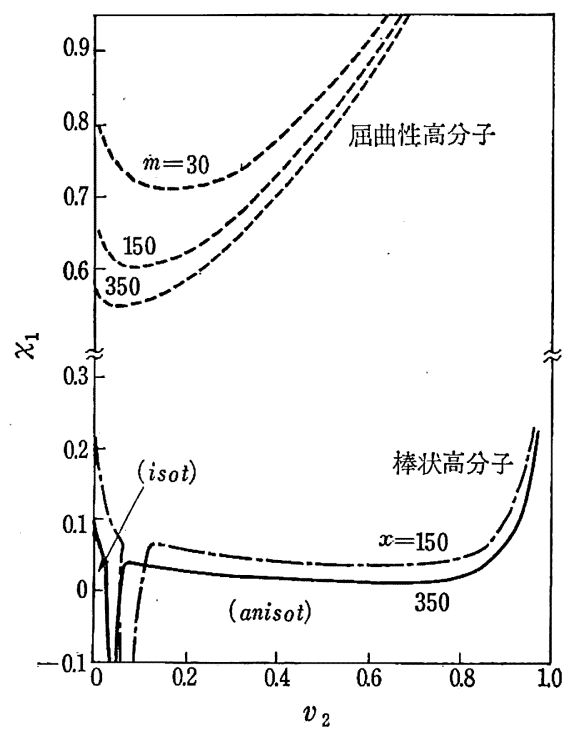

第 10 図軸比 $x=150$ および 350 の棒状高 分子の相図 ${ }^{48)}$ 。破線は $m=30,150,350$ の屈曲性高分子の相図を比較のために示 す。
すなわち希薄溶液では等方性溶液が形成されるが，右側 の曲線より下の部分では溶液は異方性すなわち棒状分子 は配向して分散するのである。四の上部に示した三つの 破曲線は屈曲性線状高分子に対するもので曲線より上の 部分では相分離が起こることを示している。 $x=150$ と $m$ =150の両者を比較してみると棒状分子では $\chi_{1}$ のわずか の正の值でもすでに相分離が起こること，すなわらェン トロピー効果の寄与がきわめて大きいことがわかるので

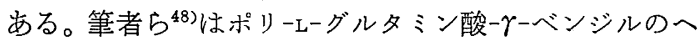
リックス溶液について実験的に上述の挙動を確かめた。

\section{4-2-2. 半屈曲性重合体}

多かれ少なかれ内部回転のために鎖の形態が变わりら るような分子鎖を半屈曲性分子鎖と呼んで括くとこれに は種々な型が含まれる。たとえば隣接するボンドベクト ルがわずかに変化しているよらな分子では分子はゆるや かに曲りくねった形をとり, 鎖の平均の広がりはかなり 大さいものになるであろう。セルロース誘導体のよらな 場合ボンド C-O の变わりで内部回転は可能であるがか さ高いグルコース残基のため屈曲性の程度がきわめて小 さいことが知られている。このような鎖の広がりを論議 するために“ミミズ状 (worm-like)” 鎖モデル49) が用 いられる。

前述の $\alpha$-ヘリックスのよらな棒状分子が一重結合に よって連結されたような分子や， $\alpha$ ーヘックスが部分的 に分子内水素結合の開裂によってほどけたよらな場合も 半屈曲性分子と考劣られる。ヘリックスーユイル転移領 域にあるポリペプチド鎖はこの類型とみなしてよいわけ である。重合度 $n$ の分子鎖が， $n_{1}$ 個のモノマーから構 成された長さ $n_{1} b_{1}$ の棒の部分と， $n_{0}$ 個のモノマーから なるランダムフライト鎖で仮定される部分とのくり返し で構成されるとして，2 乗平均慣性半径 $\left\langle S^{2}\right\rangle$ や極限 粘度数 [ク] が寺本 $5^{50)}$, Hagnauer $5^{51)}$ によって定量 的に取り扱われ，ポリペプチドのヘリックス含率の関数 として実験的な検討が行なわれている。

\section{5. 溶液物性と分子量分布}

緒諭でも述べたように高分子研究において分子量分布 の問題は基本的に重要である。それは高分子がその生成 の機構上，一般に多分散性であり，いわゆる “単分散” ポリマーと呼ばれるものに拀いても完全に分子量が均一 であるといらことは必ずしも保証できないからである。 高分子溶液研究で分子量分布に関連するものは次の四つ のテーマに大別でさるであろう。

その第 1 は分別である。これは分子量の不均一な試料 をまず溶液とし，分子量に関係する溶液の物理化学的な 
性質を利用して，分子量のそろった区分を取り出してゆ く操作である。この操作によってわれわれはかなりの程 度に分子量の均一な分別区分を得ることができる。同一 のモノマー種を用いても重合方法によって生成物の分子 量分布の型や幅は著しく異なることがあるから，分子量 分布に無関係に高分子の樥造と溶液物性の関係を調べる には分別区分を得ることが必要であるわけである。

その第 2 は分別区分に関する溶液物性の測定とデータ 処理である。分子量の均一な高分子に対して導かれた溶 液物性の理論式の検討あるいは適用にあたって，分別区 分がな打分子量に関して厳密に均一でないといらジレン マがつきをとう。すなわら，分別区分について観察され る量も平均值であり，その数平均，重量平均， $z$ 平均 分子量をそれぞれ $M_{n}, M_{w}, M_{z}$ ，また $<S^{2}>$ の $z$ 平均 を $\left\langle S^{2}\right\rangle_{z}$ ，分別区分の極限粘度数を [ク]*，浸透圧 ならびに光散乱から求まる分別区分の第 2 ビリアル係数 をそれぞれ $A_{2, O S}$ ならびに $A_{2}, L S$ とすると，分別区分 が分子量に関しかなり均一な場合には次に示す近似で分 子量均一物の物性值との対応が許される。

（a） $M_{z}$ と等しい分子量 $M$ をもった分子量均一の 高分子の $<S^{2}>/ M$ の值は $\left.<S^{2}\right\rangle_{z} / M_{z}$ に等しい。

(b) $M_{w}$ と等しい分子量 $M$ をもった分子量均一の 高分子の $[\eta] / M^{1 / 2}$ は $[\eta] * / M_{w}{ }^{1 / 2}$ K等しい。

（c） $M_{n}$ と等しい分子量 $M$ をもった分子量均一の 高分子の $A_{2} M^{1 / 2}$ は $A_{2}, O S M_{n}{ }^{1 / 2}$ に等しく，また, $M_{w}$ 之等しい分子量 $M$ をもった分子量均一の高分子の $A_{2}$ $M^{1 / 2}$ は $A_{2, L S} M_{w}^{1 / 2}$ に等しい。

これらの近似を用いることによって分別物に対する測 定量から分子量均一の溶液物性の相関を知ることができ るわけである。

その第 3 は多分散性高分子試料の各種平均分子量の決 定である。たと艺ば数平均分子量が浸透圧測定から，重 量平均分子量が光散乱測定から，ぬた， $z$ 平均分子量 が超遠心法によって決定されるなど，それらについては 多くの説明を必要としないであろう。

その第 4 は多分散性高分子試料の分子量分布の決定で ある。これには，直接分布によって preparative に分 布を決定する方法と，いくつかの（多い方がよいが）種 類の平均分子量を求め, それらから分布を analytica1 に 決定しょうとする方法との二つがある。前者の方法では カラム分別法やゲルパーミェーションクロマトグラフィ （GPC 法）が近来活用されており，後者では遠心機によ る沈降図形のモーメント法による解析が成果をあげてい る。

与克られた紙数も尽きたので擱筆することにするが，

Vol. 20, No. 229
上述した以外に相平衡や相溶性 ${ }^{52)}$, 溶液からの組織構造 (単結晶やミクロ相構造など) の顕現，生体高分子など 書ききれなかった領域も多い。溶液研究の分野は高分子 を分子のレベルで捕え，それを分子構造と結びつけると いら点で強みと，安易なスペクレーションを許さない戦 しさを持っている。

\section{文献}

1) M. V. Volkenstein: "Configurational Statistics of Polymer Chains", John Wiley \& Sons, New York (1963)

2) T. M. Birshtein, O.B. Ptitsyn (S. N. Timasheff 英訳): “Conformation of Macromolecules", Intersciene, New York (1966)

3) P.J. Flory: "Statistical Mechanics of Chain Molecules", Interscience, New York (1970)

4) G. G. Lowry: "Markov Chains and Monte Carlo Calculations in Polymer Science", Marcel Dekker, New York (1970)

5）中島章夫，細野正夫：“高分子の分子物性 (上巻)”, 化学同人（1970）

6) A. Nakajima, F. Hamada, S. Hayashi: $J$. Polymer Sci., C15, 285 (1966)

7) C. A. Hoeve: J. Chem. Phys., 35, 1266 (1961)

8) A. Nakajima, A. Saijo: J. Polymer Sci., A-2, 6, 735 (1968)

9) P. J. Flory, F. Hamada: 未発表データ

10) A. Abe: Polymer J., 1, 232 (1970)

11) A. Nakajima, S. Tanaka: SPSJ Microsymposium 1970-1, 論文集 p. 41 (1970) 京都; Polymer $J$. 投稿中 (1971)

12) I. Prigogine: "The Molecular Theory of Solutions", North Holland Pub. Co., Amsterdam (1957)

13) R. Simha, A. J. Havlik: J. Am. Chem. Soc., 86, 197 (1964)

14) V.S. Nanda, R. Simha: J. Chem. Phys., 41, 3870 (1964)

15) P. J. Flory, R.A. Orwoll, A. Vrij: J. Am. Chem. Soc., 86, 3515 (1964)

16) P.J. Flory, R. A. Orwoll, A. Vrij: J. Am. Chem. Soc., 87, 1833 (1965)

17) D. Patterson, A. A. Tager: Vysokomol. Soyed., A 9, No. 8, 1814 (1967)

18) I. Prigogine, A. Bellemans, C. Naar-Colin: 


\section{J. Chem. Phys., 26, 751 (1957)}

19）山川裕巳：高分子，19,782 (1970)

20) T.G. Fox: Polymer, 3, 111 (1962)

21) A. Bondi, "Physical Properties of Molecular Crystals, Liquids, and Glasses", John Wiley, New York (1968)

22）山川裕巳：高分子, 14, 54 (1965)

23）倉田道夫, 深津政昭 : “高分子の物性（続)”, p. 79, 化学同人（1965）

24）小高忠男，宮本武明：高分子，17，629（1968）

25) G. C. Berry, E. F. Casassa: Macromol. Review, 4, 1 (1970)

26）谷口正勝, 桜田一郎: 工化, 36, 1208 (1933)

27) 桜田一郎：化紴講演集，5，33(1940)

28) M. Kurata, H. Yamakawa: J. Chem. Phys., 29, 311 (1958)

29) H. Sotobayashi, J. Springer: Fortsh. Hochpolymeren-Forsch., 6, 473 (1969)

30）稲垣 博：化学增刊, 27, p. 21 “共重合体の溶液物 性”化学同人 (1967)

31）村上洋一 : "Studies on Copolymer in Solution", 京都大学博士学位諭文 (1968)

32) 大沼 宏: “Thermođynamic and Conformational Properties of Block Copolymers in Solution", 京都大学博上学位諭文 (1969)

33) W. H. Stockmayer, L. D. Moore Jr., M. Fixman, B. N. Epstein: J. Polymer Sci., 16, 517 (1955)

34）桜田一郎, 中島章夫 : 高化, 3, 103 (1946)

35）阿部充雄, 日比野清志, 田形信雄, 本間辉武：ゴム 協会誌，40，930 (1967)

36) 中島章夫：高分子工学講㭫第 4 巻，293 ページ, “分枝高分子の形態”, 地人書刢 (1967)
37）倉田道夫：化学增刊, 27, p. 7, “非線状高分子の溶 液論”，化学同人 (1967)

38）阿部充雄, 倉田道夫：化学增刊， $43, \mathrm{p} .85$, “溶液論 的方法による長鎖分岐度の決定”，化学同人 (1970)

39）倉田道夫，岡本宏義，阿部充雄，岩間真道，本間輝 武：第 19 回高分子討論会予稿集，策 2 分冊, p. 671 (1970 京都)

40) S. A. Rice, M. Nagasawa: "Polyelectrolyte Solutions", Academic Press (1961)

41) 永沢 満 : “高分子の物理”, 第 15 章, 朝 倉畫店 (1963)

42) 永沢 浾, 高橋 彰：高分子工学嵒座第 4 巻 p. 373 地人書館 (1968)

43）伊知典夫 : 高分子の物性， I， p. 117，化 学 同人 (1965)

44) A. Takahashi, M. Nagasawa: J. Am. Chem. Soc., 86, 543 (1964)

45) S. Tanaka, A. Nakajima: Polymer. J, 1, 505 (1970)

46) A. Nakajima, H. Sato: Bull. Institute Chemical Res. Kyoto Univ., 47, 177 (1969)

47) P. J. Flory: Proc. Roy. Soc., A 234, 73 (1956)

48) A. Nakajima, T. Hayashi, M. Ohmori: Biopolymers, 6, 973 (1968)

49) O. Kratky, S. Porod: Rec. Trav. Chim., 68, 1106 (1949)

50) A. Teramoto, T. Norisue, H. Fujita : Polymer J., 1, 55 (1970)

51) G. Hagnauer, W. G. Miller: Biopolymers, 9, 589 (1970)

52）中島章夫：“高分子の相溶性と分散状態”，1971 年 版プラスチック年藍，工業調䍒会，Jan. (1971)

1970

年度版

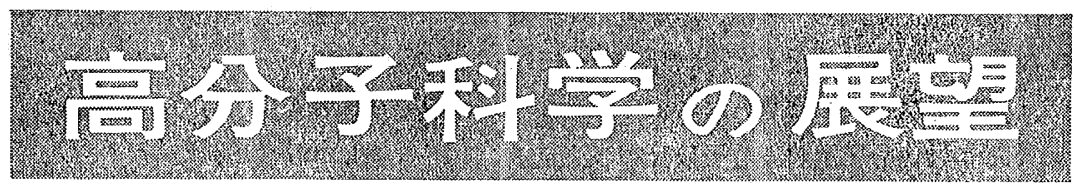

編集委員長 東大教授 岩 倉 義男

高分子学会編集 B 5 判 280 頁 8 ポイント 2 段組 定価 2,000 网

最近の高分子科学の分野はきわめて広範・多岐にわたって扣りますが，これら全分野を絧羅 したレビューはあまり例がありません。

昨年の高分子学会年次大会のレビュー講演を骨子として，さらに整備し，単に展望記事のみ でなく各分野の文献を十分に紹介したもので，最近の高分子科学の针向と進歩、さらに将来 への展望が十分ご理解いただけるものと確信いたして执ります。この「高分子科学の展望」 1970年度版は第 1 巻であり，今後 Annual Review として，毎年刊行するよら考㝋て拉ります。 申込先 丸 善 (株) (104 東京都中央区日本橋通 2-6, 電話東京 (03) 272-7211) 